\title{
Performance Objects of Muḥarram in Iran: A Story through Steel
}

\author{
Annabelle Collinet \\ Curator, Département des arts de l'Islam, Musée du Louvre, Paris, France \\ annabelle.collinet@louvre.fr
}

\begin{abstract}
Some Muharram ceremonies in Iran today, such as taziyeh (ritual theatre) and dasteh (procession), often involve metal artifacts. They are commonly made of steel (mainly armor elements, arms, sculptures, and vessels). Many objects of similar types, generally without any historical data on their original contexts, are preserved in Islamic art collections. The present research proposes to identify these objects as Muharram performance objects. Based on two large collections (Paris, Musée du Louvre and Musée des Arts Décoratifs), this article aims to relocate them in their likely ritual contexts, especially those developed in the late Qajar period (from 1850 onward), and to look further into the past of their Safavid (1501-1722) models. Made of forged steel and inlaid with precious metals, these productions from the late Safavid period to the present day suggest the durability of some models with a strong visual identity and highlight the recurring use of this metal in Shi'a devotional art in Iran.
\end{abstract}

\section{Keywords}

procession - ritual theatre - 'alam - costume - arms and armor - steel - sculpture - Imam Ḥusayn

The visual culture of Shi ism, which has grown as a research topic over the last decade or so, is mostly approached through the study of images, ${ }^{1}$ rather than through the study of three-dimensional objects, which are nevertheless part of the same material and visual context. Dealing with Iran in the Safavid (16o1-1722) and Qajar (1786-1925) periods, many objects linked with Shi'i rituals and represented in paintings, printed images, and pictures, are preserved in museums and private collections. Thanks to their ancient descriptions and representations, the artifact types involved in Muharram public rituals of the Safavid and mainly Qajar periods are easy to identify in Islamic art collections. Some of them have contemporary counterparts that can be seen across the country in present-day Muharram rituals. These important manifestations of piety flourished during the Qajar period (Algar, 1991, pp. 724-6), which appears to be a turning point in the history of Shi'i visual culture, as evidenced by the steel object types presented in this article.

The sacred month of Muharram commemorates the martyrdom of the third Shici Imam, Husayn (d. Muharram 61/October 68o) son of 'Alī b. Abi Ṭālib, and of his seventytwo relatives and companions at Karbala, in southern Iraq. They were all killed by the 
armies of the Umayyad Caliphate, except for one male survivor: Husayn's son ‘Alī Zayn al-Ābidin who became the fourth Imam. The rituals associated with this month culminate on the tenth day, or 'Ashurā. Muharram objects are highly visible as supports of devotion and activation with the sacred in contemporary Iranian urban contexts. The number of artifacts then used and displayed, particularly in large and mediumsized cities of Iran, is impressive, and their nature and types are as diverse as the rituals themselves and the myriad ways in which they are performed today in Iran. ${ }^{2}$ When steel artifacts are used, most common are arms and armour, and 'alams with vessels and sculptures. They are visible in Tehran, in the provincial capitals across Iran, such as Ardabil, Qazvin, Qom, Isfahan, Yazd, Kerman, Gorgan, Mashhad and Semnan, and in some of the more modest cities in Qazvin Province or Bijar. Contemporary Muharram rituals are well-documented in images and videos that are widely available on the internet, and through sparse anthropological research across Iran. ${ }^{3}$ The objects visible in Iran today are recent productions, which provide insight into the nature and use of more ancient objects that they seem to replicate. Therefore, this article is not concerned with present-day Muharram accessories and costumes, but rather treats them as a point of entry into the identification and interpretation of some productions and examples of devotional art from the Safavid to Qajar Periods, particularly steel objects.

Here, I propose to revisit ancient objects and to examine use and meaning, drawing on what has been documented and recorded by scholars and observers, both contemporary and from the past, in order to study these objects made of steel and to situate them in a continuum from the Safavid and Qajar periods to the present day. On this basis, I propose that these artefacts offer us a glimpse into the performance of the rituals. The objects presented in this article are held in French public collections and are rarely linked to devotional contexts in their museum environment. Along with many other museum objects in Islamic art collections, they illustrate the question of identification of devotional art, and more broadly, the issues of contextualization and sociology of objects, especially in museums of fine arts. The artifacts grouped here were acquired as military and decorative arms and armour and, as decorative objects, are representative of the same collection types found in European museums of fine and decorative arts from the late nineteenth century onward. These objects, which constitute only a sample of Muharram performance artifacts, were mainly produced between the late eighteenth and late nineteenth centuries. Until the late twentieth century, they were relatively neglected in scholarly and museum studies. The nineteenth century is now an established topic of research in Islamic art history. Furthermore, studies on important arms and armour collections in which the Qajar period is well represented were published in recent decades. ${ }^{4}$ The recent Louvre-Lens exhibition about Qajar art ${ }^{5}$ was an opportunity to present a complete standard and some sculptures made for 'alams, preserved in different French collections (Collinet, 2018). Extending the subject, the present article is a general overview of object types from mainly the Qajar period, possibly made for the most important Muharram commemorative rituals. Arms, armour vessels, and sculptures are interpreted here as costumes and accessories for ritual processions and theatrical performances.

The sets of objects displayed and used today for taziyeh (ritual theatre) and dasteh (procession) are worn or carried by actors/participants and always in motion. Some elements of armour and 'alams (battle standards), including vessels, sculptures, and arms, can be observed in contemporary rituals performed in a few urban centers in Iran. These objects are made of metal, steel or damascened steel to be precise, and inlaid with silver and gold. Similar materials, visual aspects, and significations are used for the objects in both rituals and are here introduced as groups of performance artifacts. During present-day public rituals, the participants' bodies are very strongly involved. Because they 
re-enact Husayn's passion and death, the rituals are incredibly demanding. Participants use movement, voice, emotions, and mortifications, in addition to costumes and props, to commemorate the martyrdom of the Imam and his companions. In these rituals, the relation between the earthly body and the spiritual body, ${ }^{6}$ and the senses seem to be engaged. Many of the objects that are staged, covered, worn, or supported are directly related to the body and also bring forth the relationship with the sacred.

The artifacts preserved in the Louvre and in the Musée des Arts Décoratifs collections, identified as related to Muharram's rituals and in particular to 'Ashurā, shall be presented and discussed in this paper mainly with the following underlying aspects: First, it will discuss the types of steel objects involved in their devotional contexts, documented through some contemporary Muharram rituals; Second, with reference to the objects held in museum collections, it will discuss their relationship with the historical period to which they were witnesses, as they are part of a specific visual culture that is to some extent anchoered in the Safavid past, but was well established by the latter half of the nineteenth century. The steel objects used in rituals today thus transmit and activate in the present several past founders, Karbala, state Twelver Shi'ism, and the development of Muharram's rituals. There is a connection with the time of the Imam and an activation of his presence through the reproduction of visual references (time is both erased - the original massacre becomes a cosmic battle that exists outside of time - and accumulated by the types of artifacts used and the models to which they refer, or even copy). The third theme addressed here concerns the material and its craftsmen. The artifacts, often made of steel, whether these are produced and used today ${ }^{7}$ in Muharram rituals or are preserved in the museum collections from the Safavid to Qajar Periods, connect this peculiar material with a Shi'i devotional culture, and therefore their makers as well. Steel is, along with iron, the material of military equipment par excellence. During the Qajar period, it was also used for objects (containers, sculptures) that, as shall be seen below, were partly devotional in nature and related to the votive gift (nazr). These productions were carried out by the same blacksmiths and damascene makers who produced weapons and 'alams. The blacksmiths, like other bazaar guilds, were organized in futuvvat and janvanmard circles and communities. Since the Safavid period, they have been directly involved in the collective transmission of the story and drama as participants and followers. They produced the objects used for the reenactment of Karbala and they participated as futuvvat circles/guilds and patrons of Muharram public processions (Babayan, 2002, p. 218).

Dasteh is possibly the earliest Shici ritual in the public sphere: the first recorded mourning processions commemorating Imam Husayn took place as early as the tenth century AD in Baghdad, and became highly developed in Iran from the Safavid period onward (Chelkowski, 1985 and 1994). If one refers to recent studies, dasteh and tazi$y e h$ (ritual theatre) often seem to be treated as two distinct subjects: Taziyeh seems to attract the most scholarly interest, from a theatrical and musical to an anthropological standpoint. It seems that few recent works deal with the rituals as two historically intertwined manifestations. As Chelkowski's foundational studies have shown, the theatre was originally a part of the procession, before the two became separate ambulatory and stationary rituals. The passion play that was born around the middle of the eighteenth century (Arnold 1889, Chelkowski, 1985 and 2009) was at first without dialogue or theatrical form. It emerged from the procession, then "the parade costumes became stage costumes," but "the umbilical cord between the procession and the drama was 
never completely severed." Scenes from the drama are still part of the processions today and, even though they are less common, mobile forms of taziyeh also exist (Chelkowski 1985, p. 23). In 1787, William Francklin's account (Shahriari, 2006, p. 40) indicates, according to Chelkowski, the transition to "ritual drama," where taziyeh is extracted from the dasteh. It is suggested that the static and ambulatory aspects of the ritual emerged when the transition from the costumed parade/procession to the passion play was complete, and the latter became detached from the procession and was performed in particular places of gathering: the takiyeh or husayniyeh. These two rituals became highly developed in the second half of the nineteenth century, during the reign of Nāșer al-Dīn Šāh Qājār (r. 1848-96). According to written and visual accounts, the performance objects worn and used in the two great public rituals were the same until the 185 os. The middle of the nineteenth century constituted a turning point in the history of Muharram rituals and that of the devotional objects produced for this purpose. The identification of the different objects worn by the participants and named by direct witnesses is a precious source of information about the props. They show how these attributes visually touch the witnesses and are fundamental parts of the ritual itself and its significations.

Many seventeenth and eighteenth-century European accounts ${ }^{8}$ describe processions in which living and moving tableaux of the Karbala martyrdom narrative were represented, with the following attributes: "standards, banners, flags, ensigns, turbans, helmets, band instruments and a variety of weapons such as swords, axes, bows and arrows, lances, shields, and fire-arms" (Chelkowski 1985, p. 21). In 1737, a mobile scene (majles) of Husayn's martyrdom performed during a processional taziyeh (ta'ziyeh kāravāni) was described by Thomas Salmons and Matthias Van Gogh (Chelkowski, 2009): their testimony mentions that accessories such as weapons and flags were used during the ritual. In 1787 Francklin (Shahriari, 2006, p. 40) describes processions in Shiraz with "representations" of characters and the place of martyrdom, troops depicting the soldiers of the Battle of Karbala, with banners and distinctive signs. He also mentions the use of (real) animals in the representation, such as doves and horses.

After the written testimonies and the engravings that document some dasteh of the Safavid period, the rituals of the Qajar period were well recorded in written accounts, engravings, paintings, pictures, and movies ${ }^{9}$ that describe and represent both dasteh and taziyeh. The most famous takiyeh, the Royal Theater (takiyeh dawlat) built in Tehran in the 1870s, is for instance one of the common subjects of paintings and pictures used to illustrate taziyeh development in Iran during the second half of the nineteenth century. Many pictures exist. Not that many of the plays, which were photographed probably because it was technically impossible to take pictures without long exposures but rather of the actors posing in full costume and wearing their arms and armour accessories (fig. 5, fig. 7). They enable us to identify the types of artifacts used in taziyeh and dasteh rituals until the end of the Qajar period (1925).

As in these earlier periods, contemporary Muharram performance objects are polysemic. Arms, elements of armour, and other objects of processions and devotional theatre are visual markers of the Battle of Karbala and its narrative. In present day taziyeh, in the case of theatrical performances where budgets are available for costumes, the actors may wear helmets, coats of mail, shields and swords. The same attributes, visually similar, can be found today on large crossbar 'alams carried in front of the processions, as documented by pictures and films made by observers in large cities across Iran. ${ }^{10}$ The similarity with the types of arms and armour known from the Safavid period onward is striking (fig. 3). This equipment participates in the activation of the presence of the characters involved in the Battle of Karbala, and it is also through these objects that the Martyrdom of Husayn and his companions is signified. These signs used in the 
devotional performances of play and procession are identical to those of the battle. They simultaneously concentrate the vision, activation, and narration of the martyrdom, for they may be considered as a representations of the military equipment, carried, and worn by the martyrs en devenir. The martyrs are sometimes suggested even more clearly through the composition of the soldier's/martyr's attributes that draw a silhouette of the soldier/martyr wearing a helmet, armed with a sword, and protected by a coat of mail and a shield. This representation of the martyr is enhanced when the anonymous/eternal soldier is replaced by close-up shots of contemporary martyrs of war (Parsapajouh, 2019; Gruber, 2016).

Contemporary dasteh, performed with large to huge crossbar 'alams that open the funerary processions, display the most visible and imposing supports of Muharram ceremonies. These 'alams can be as long as a street is wide and thus require several men to carry them (fig. 1), while smaller ones are carried by boys (fig. 2). ${ }^{11}$ What can be observed on them, and which can vary considerably according to the numerous examples of 'alams pictured since the early twenty-first century across Iran, is very close to what is known about 'alams from the late Qajar period. Besides arms and armour, and steel animal sculptures, vessels are clearly referenced in these models. It was during the nineteenth century that a most striking and fascinating artifact emerged: the steel assemblage constituting the crossbar 'alam. Pictures document the use of horizontal 'alams, which did not exist before the late Qajar period (fig. 6). They are characteristic for Iran and seem to have been established simultaneously with the development of taziyeh, when the distinction between static and ambulatory rituals was made. These impressive artifacts thus seem to visually characterize many dasteh since the second half of the nineteenth century. The 'alam can be seen as a portable stage, on top of which the objects are visual substitutes of the words of the story told in the theatre. They recount the drama and are part of the devotional act performed by the participants who carry and follow the 'alam.

As observed by Chelkowski (1991, p. 771), these objects are symbolic of Husayn's army, and the carriers and participants are his troops. The objects displayed on the large crossbar are mirrored from the center, occupied by the main vertical standard.

FIGURE 1

'alam prepared for dasteh in Karaj (near Tehran), Islamabad area,

Muharram 2007

(C) S. PARSAPAJOUH

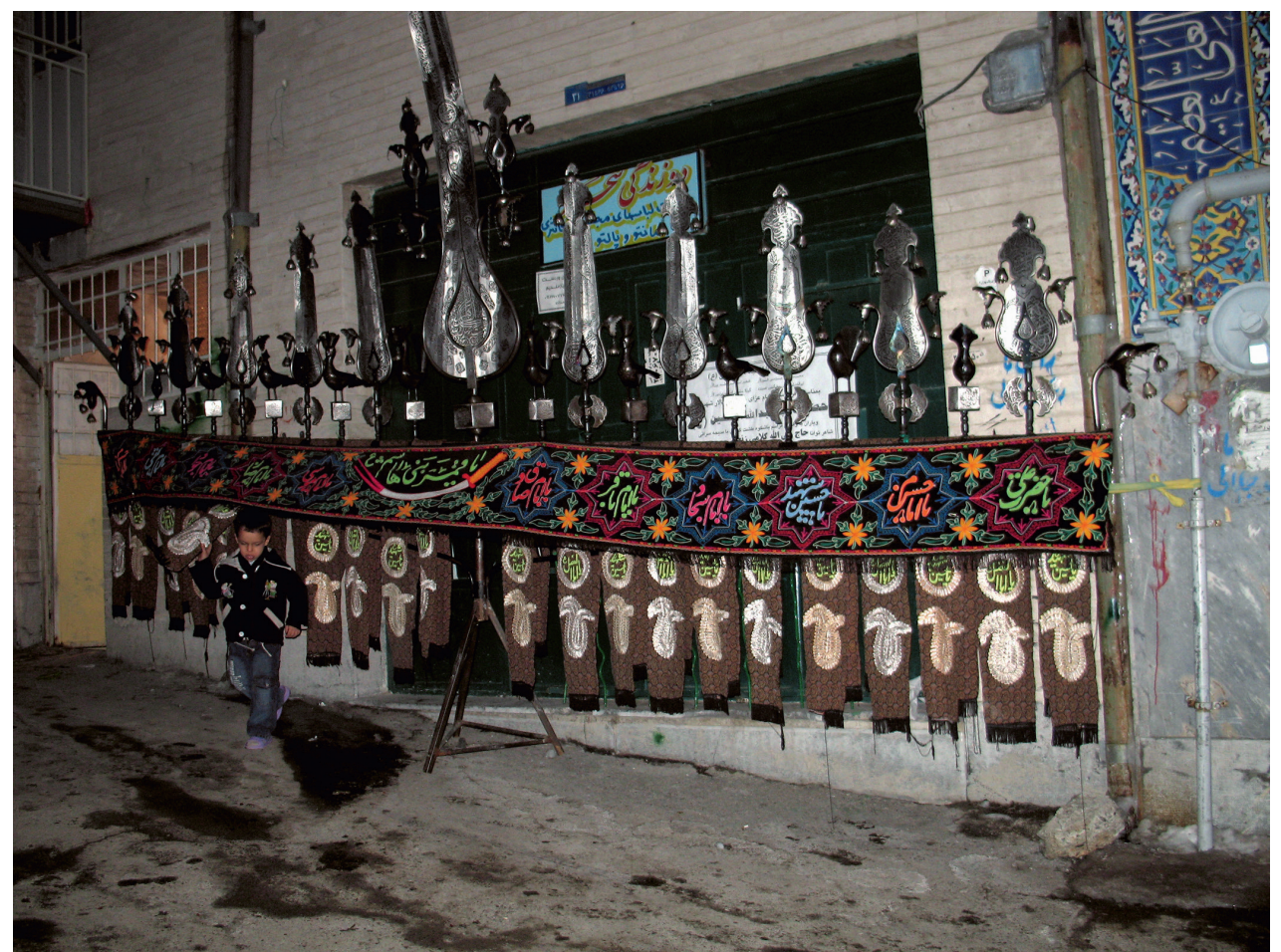




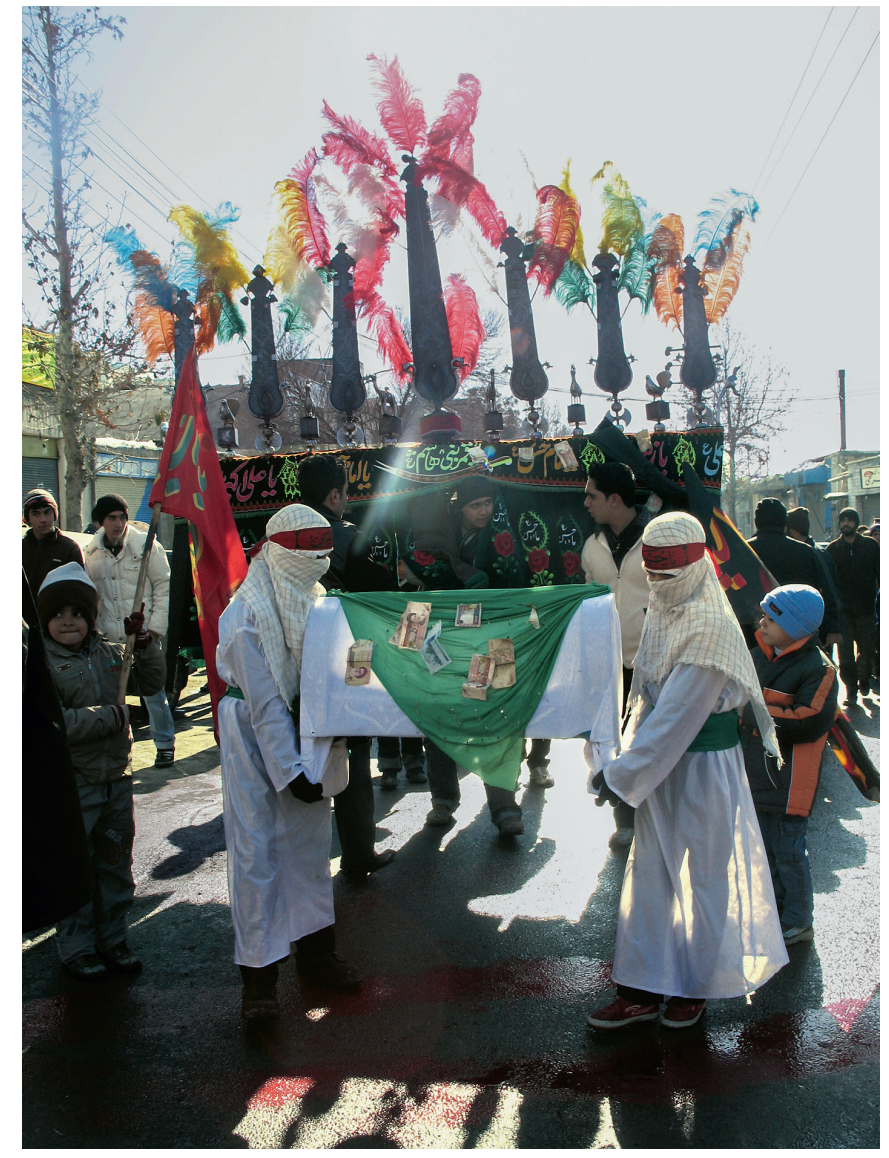

The steel assemblage organized around it can be composed with a repetition of identical sculptures and banners, or they are paired, and different types of sculptures and objects are mirrored from the center to the extremities of the crossbar. Every horizontal 'alam is different, but the central calligraphic sign usually bears the names of the Prophet and the most venerated figures of Twelver Shicism, and is surrounded by sculptures of symbolic animals like birds (including the peacock, which symbolizes the hidden Imam or Mahdi), elements of armor, such as helmets and coats of mail, swords, other standards and vases. During the Qajar period, sculptures of fruits were also made for the horizontal 'alams (see below). The latter objects tell the story of the martyrdom of Karbala through thirst and hunger and are linked to votive gifts (nazr) for the martyrs. ${ }^{12}$ The zoomorphic sculptures also represent the story of the martyrdom, and the figures they invoke (Collinet, 2018). For instance, the lion is immediately identified with Imam 'Alī, but it also represents the lions that protected the bodies of the martyrs on the Karbala battlefield. ${ }^{13}$ Lions were also associated with the image of the Qajar Shah, and the emblem of Iran was a Lion/'Alī with the sun. ${ }^{14}$ Karbala's sign-objects are multiplied in both the form of the horizontal 'alam and the props used in the taziyeh. In devotional theatre, the story is accompanied by the presence of vertical standards from which other objects are absent: they are carried on the stage and around it by the actors.

Twelver Shicism became the state religion of Iran in 907/1501 with the young founder of the Safavid dynasty, Šāh Ismacīl (r. 1501-24). He was the leader of the Ṣafaviyeh Sufi
FIGURE 2

'alam carried by boys in Karaj (near Tehran) Islamabad area, Muharram 2007

(C) S. PARSAPAJOUH 
order and a descendant of its founder, Šayh Șafī, whose religious order settled in Ardabil in the thirteenth century. Šāh Isma'îl's genealogy was rewritten in order to present the Safavid dynasty as descendants of the Prophet Muhammad, through the seventh Imam (Mūsā Kāżim). ${ }^{15}$ The intertwined relation between the dynasty and Shi'i authority materialized through the foundation of religious/pilgrimage architecture in urban spaces, and through public rituals. The Safavids sponsored Muharram rituals and the central role of the sultan in the ceremonies is recorded in historical accounts of the sixteenth century (Ghaffary, 1984, p. 367; Rahimi, 2012, p. 200). They promoted the legitimacy of their political/earthly power and were responsible for the dramatic changes in the rituals that occurred at that time, and that were largely continued by the Qajars. The public rituals were greatly developed from that time onward. They have helped spread the Twelver Shici faith in Iran and contributed to the policies of conversion developed in a country that was predominantly Sunni (Chelkowski, 2009; Aghaie, 2004, p. 3).

Descriptions of Muharram rituals and related objects go back to the Safavid period. ${ }^{16}$ Arms, armor, and vertical standards were involved in the dasteh. These objects date to the sixteenth-eighteenth centuries and many of them are part of museum collections, such as those of the Louvre, and were possibly used in Safavidperiod rituals (fig. 3-4). The arms and armor used at the time were probably real weapons of war, and their status changed with the purpose, becoming supports of rituals and weapons of a symbolic battle. It seems to be during this same period, i.e from the sixteenth century onward, that the 'alam became the most emblematic artifact of devotion in Muharram rituals. It is the material object par excellence, associated with Imam Husayn's cult, and preserved in the treasures of his sanctuary. ${ }^{17}$ Some standards are considered as relics of the events of Karbala, particularly the one carried by 'Abbās, the 'alam dār or standard bearer of Ḥusayn's troops. ${ }^{18}$ Few 'alams held in Iranian sanctuaries and that were brought out for Muharram rituals were historically studied, but in the case of the treasury (khazineh) of the Ardabil Safavid sanctuary and its eighteenth century inventory, Kishwar Rizvi considers the 'alams and other precious objects held in the sanctuary as spiritual and temporal relics that are to be understood as memory objects (Rizvi 2015, p. 299).

The symbolic objects of the Muharram rituals developed especially from the seventeenth century onward. During the reign of Šāh 'Abbās, these rituals occupied the public space and developed into major processions (Rahimi 2012, p. 200-1). Sets of steel war artifacts created at that time reflect new fundamental aspects of ritual signification and its links to the public mourning space. To Rahimi (2012, p. 247), the growth of "representational armory objects" and "memorial objects" ('alams) in dasteh, besides visibility of death with display of empty coffins for instance, is a "key illustration of how metaphors of martyrdom and sacrifice are staged to produce a ritual space of death." These objects connect to the collective body in the ritual, to the metaphor of blood, death, and sacrifice of martyrdom. According to the same scholar, the accounts show "the close connection between Safavid war campaigns and the collective ritual performances organized by the new military order (...) by the turn of the seventeenth century" when Isfahan was built and a new military order emerged to replace the Qizilbāš faction.

There were witnesses of the use of artifacts of battle in the rituals: in 1602-16o4, António de Gouvea describes a procession in Shiraz with representations of the Karbala characters, in which displays of mourning and ritual battles were performed by urban factions and guilds that were originally organized by futuvvat circles, especially wrestler guilds. According to Babayan, artisans, and craftsmen, thence the futuvvat brotherhood or communities, were a major part of the Safavid order, and their role seems to be key to understanding Safavid religiosity and social power. The craftsmen in bazars and coffeehouses were in contact with storytellers and westlers, who were also organized 


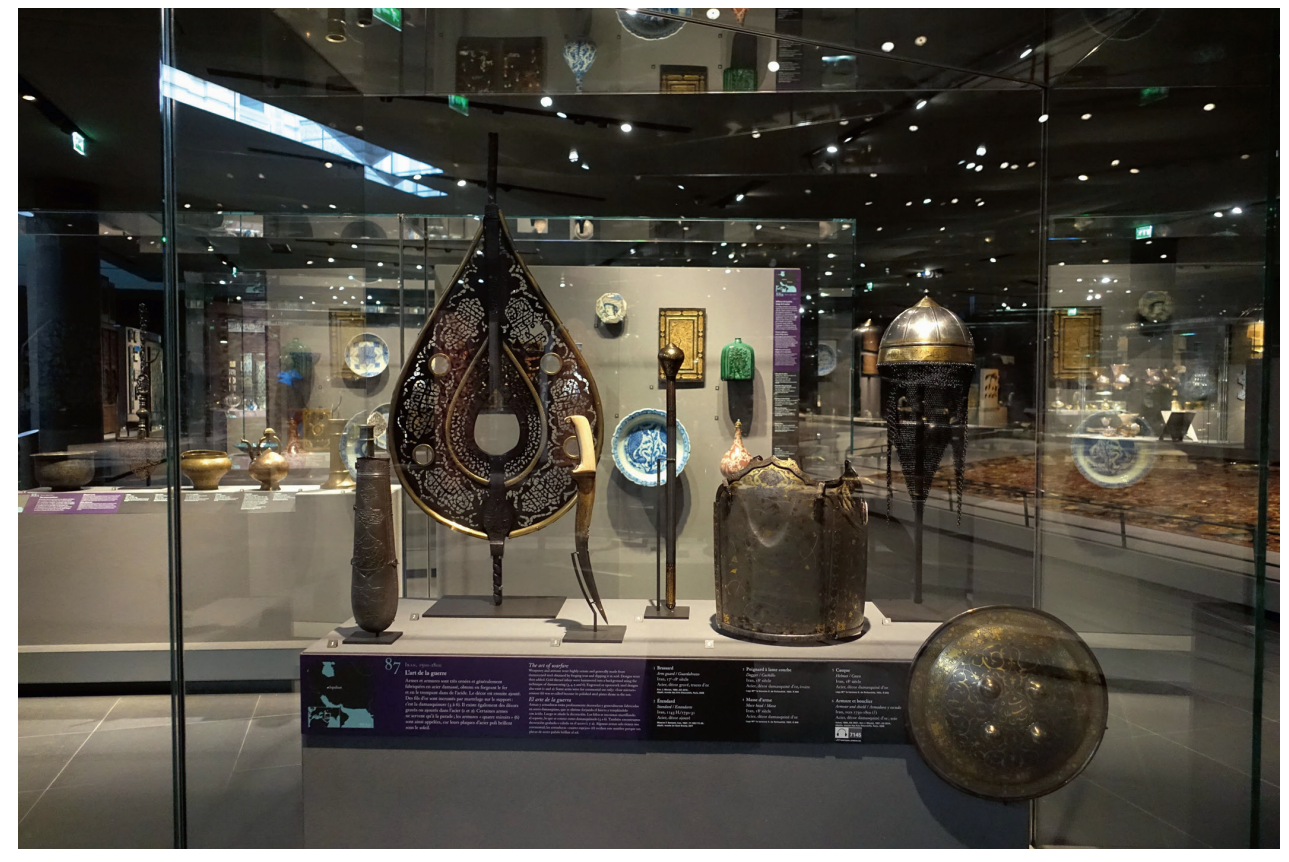

in guilds. Artisans and guild life in Isfahan under Safavid rule were directly related to public rituals, for processions were led by guilds in the capital city in the seventeenth century. Furthermore, "Stories and poetry recited in craft circles, where warriors and artisans joined together in chivalric vows of obedience and loyalty, acted as a medium for both sharing an (re)shaping the past." It is in this context that the story of the martyrdom, i.e. Kashifi's Garden of Martyrs (Rawzat al-Šuhadā), was told. ${ }^{19}$ The actors of the written and the makers (the blacksmiths) of the visual devotional supports of the performed drama were, in this context, connected producers of the ritual of dasteh in the public space.

The ritual combats inaugurate what Rahimi calls a "carnival military procession." Pietro della Valle also recounts that on 'Ashurā 1618 in Isfahan combats between the guilds took place with spears and swords, and flags and standards were used and carried by horsemen on mounts (Rahimi, 2012, pp. 222-4.). He also makes mention of trays carried on the head by participants in the procession, containing trophies of arms: on these trays were accumulations of weapons "and other items." The fighters carried them to the royal palace if they were victorious. ${ }^{20}$ The $1618-19$ processions were a "display of ritual representative objects, like banners, turbans, and ceremonial armory, (which) marks a major development from the 1540 version of the ceremonies, in which symbolic practices primarily appeared to rely on corporeal self-injury performances of the ritual participants." The other seventeenth century European accounts of Muharram rituals reveal, according to Rahimi, "an increasing elaboration of visual performative practices."21 The carriers of the battle signs bore a heavy weight, as, from the Qajar period onward, battle standards were increasingly adorned with objects that symbolized the Karbala battle and its narrative.

These accounts from the eighteenth century allow us to study the rituals' development and the shift from ambulatory to static performances that marks the birth of tazi$y e h$. They also attest to the development of the scenes performed in full costumes and with realistic accessories, bloody tableaux vivants, and live animals, like pigeons (that flew to Medina and announced Husayn's death) and (pretend) wounded horses representing Husayn's - and his brother's and standard bearer 'Abbās's - mounts (Shahriari, 20o6, p. 39-42).
FIGURE 3

Musée du Louvre, DAI, showcase titled "the art of war" Safavid Period. The fragmentary 'alam (H. $1.10 \mathrm{~m}$ ) is on loan from the Musée du Quai Branly-Jacques Chirac, Paris, inv. 71.1967.111.66 (C) A. COLLINET 
FIGURE 4

Shield (interior and exterior) with hunting scenes and inscribed in thuluth: with "Šāh Sultān Ḥusayn," and a poem that compares the shield with the full moon and the sun. The Safavid shah could be Husayn I (r. 1694-1722) or Husayn II (r. 1753-86). Paris, Musée du Louvre, on loan from the Musée des Arts Décoratifs, inv. AD 8574

(C) MUSÉE DU LOUVRE, DIST. RMN - GRAND PALAIS / CLAIRE TABBAGH / COLLECTIONS NUMÉRIQUES
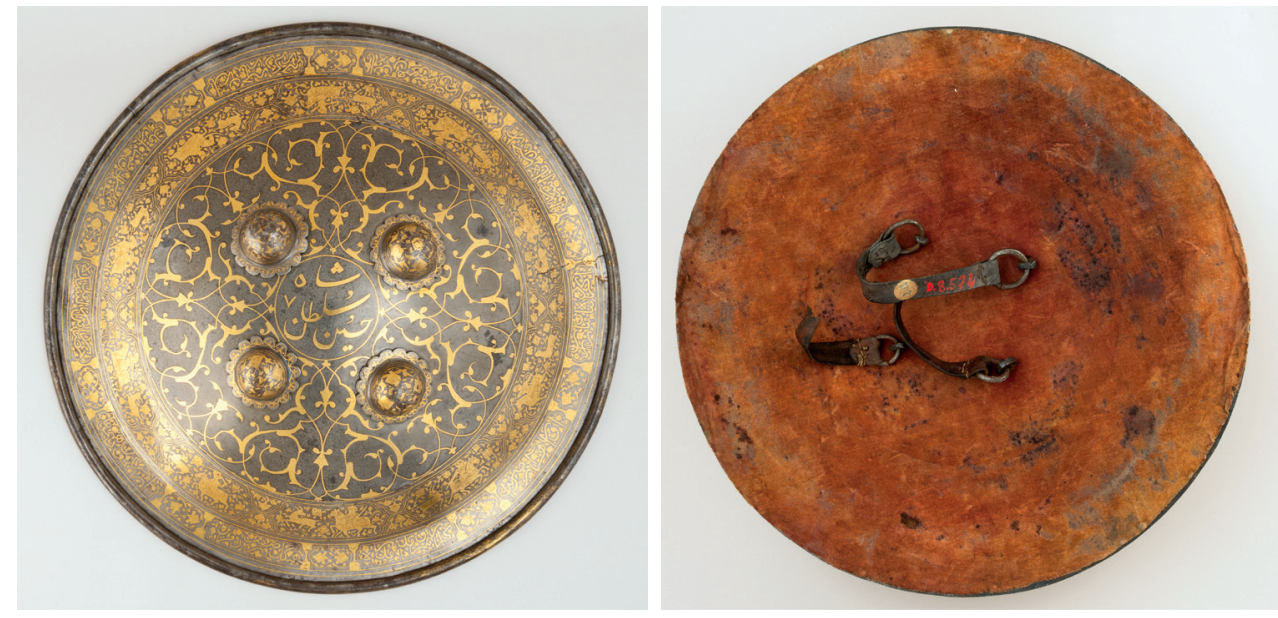

The Qajars were originally minor members of the Safavids' Qizilbāš tribal confederacy. Unlike the Safavids, they did not claim descent from an Imam, and their legitimacy was debated by Twelver religious scholars. The Qajar dynasty was finally established on the Safavid throne on 3 Shawāl 1212/21 March 1798 - which was Nawrüz and the 'Td al-Fițr, Persian New Year and the end of Ramadan respectively - when Fatḥ 'Ali Šāh crowned himself in Tehran. ${ }^{22}$

Between the reign of the two great Shici dynasties of the Safavids and the Qajars, ruled Nāder Šāh, his Afsharid successors, and the Zands ruled, although the unity of the Safavid realm was lost during this period. The Zand state represented half of the Safavid dominions, while Khurasan was part of the Afsharid kingdom (1736-96). ${ }^{23}$ The "quasi-Sunni religious policy" of Nāder Šāh (r. 1736-47), who considered the Safavids' faith heretical, ${ }^{24}$ his exile of Shi'is to Iraq, and his promulgation of a new "Ja 'fari" faith (Perry, 1991, p. 36) was followed by the "neo-Safavid Zand state" (1751-95) under Karìm Hān who encouraged the return of exiled Shi'a to Iran, and defended their access to the Najaf and Karbala Shi' $i$ shrines in Iraq after the loss of Mashhad to the Afsharid dynasty (c. 1747-96).

The accounts of travelers and residents (European, Turkish, Russian) in Iran from the late eighteenth, and especially the nineteenth centuries (recorded by Floor, 2005, and Shahriari, 2006), describe the processions and the rise of taziyeh, and mention the kinds of objects that were used in street processions, theatrical processions, and theatrical performances. Some testimonies focus on the 'alams and the strength of men who carry them, others on the costumes of taziyeh actors. James Morier, writing in 1809, mentions the mesh ribs, shields, spears, banners, armors, and the horse, camel, and elephant caparisons. He states that the weapons and armor, as well as the animals involved (except for the lion) were real. Ouseley, a few years later, recalls a procession that included horses and blood stained wrestlers armed with daggers and swords. Wills, writing in Isfahan in 1886, describes processions as part of taziyeh "of men, women, demons, prophets, soldiers." Benjamin (1883-5) talks about costumes consisting of, for example, a mesh rib and a large helmet 'of olden times' with feathers for 'Abbās. Toward the end of the nineteenth century, eyewitness accounts mention the colors of the costumes, especially green and red. A banner in a procession preceding the drama (tazi$y e h$ ) is also described by Morier in 1812 and 1818 : "First came a stout man, naked from the waist upwards, balancing in his girdle a long thick pole, surmounted by an ornament 
made of tin, curiously wrought with devices from the Koran, in height altogether about thirty feet." He adds that a "high and cumbrous pole was brought into the scene. It was ornamented with different colored silks and feathers, and on the summit were fixed two curious weapons made of tin, and intended to represent the swords of Ali. This heavy machine was handled by a man who, having made his obeisance to it (by first bowing his head, then kissing it) took it up with both his hands, and then, amidst increasing applause, balanced it on his girdle, on his breast, and on his teeth." Engravings that illustrate Morier's description of 'alams document the early nineteenth century 'alams used in dasteh, which were vertical. ${ }^{25}$ Before the crossbar style of 'alam appears, other heavy ritual objects were carried by several men in dasteh: symbolic coffins, for instance, are also mentioned in James Morier's account. The same relation to the body is present when the 'alam is carried on the shoulder. It can be linked to the symbolic bodies of the martyrs carried on the 'alams.

During the reign of Nāṣer al-Dīn Šāh (r. 1848-96), processions and taziyehs were often sponsored; by the shah, the court and the elites, rich merchants, and guilds. Important commissions were made for actors, wrestlers, and costumes (fig. 5). In Tehran during the Qajar era, the center of urban and religious life was the bazaar, which contained many takiyeh and mosques. Takiyehs were linked to processions, because they organized them; dasteh would go from takiyeh to takiyeh. Both taziyeh and dasteh involve the recreation of the battle, complete with weapons and armor. The objects of war thus became objects of devotional rituals through the commemorations of the Karbala drama. They were used by the hundreds in the great Qajar theaters, because entire armies were fighting around the stage. Similarly, the same objects were displayed in processions where the attributes symbolizing the battle were integrated: 'alams, banners, helmets, weapons (axes, bows and arrows, spears, guns), and military musical instruments.

There are countless steel objects in public and private collections, mainly in Europe, North America, and Iran. They include arms, armor, sculptures, and other objects such as vessels. Historical data and ownership history of the objects included here from French collections are relatively scarce. In museums of Fine and Decorative Arts, as well as in military collections, weapons and armor are treated primarily as military equipment. They are often described as ceremonial and processional weapons, but nevertheless of a military nature. The occasional sculptures and vessels are rarely related to devotional contexts: they are considered decorative objects. The many peacocks, felines, roosters, deers, and doves preserved are usually not recognized as parts of much larger assemblages, such as the aforementioned horizontal battle standards (fig. 6). The Shi'i/ devotional dimension of their possible intended use is thus rarely identified. ${ }^{26}$ It is in museums of ethnography that another interpretation, related to devotional practices, is proposed for artifacts related to Muharram ceremonies, particularly processions and ritual theatre. They can be seen as performance objects, the concrete elements of visual culture enacted by the rituals: their attributes, signs, and costumes were also represented in different media during the Qajar period. In this sense, the narrative paintings depicting the drama of Karbala represent events with cumulative depiction - to use Marzolph's term (2019, p. 148) - as the horizontal standards display the cumulative signs of the events.

Produced in very large numbers, not all of these types of artifacts were made for religious purposes. Many were sold to travelers or intermediaries, who brought them to Europe, on the rapidly expanding art market of the end of the nineteenth century, as weapons highly appreciated for the composition of walled trophées d'armes; as decorative objects and house sculptures. Identical productions of steel objects did not always have the same meaning, this depended on their material and symbolic functions.

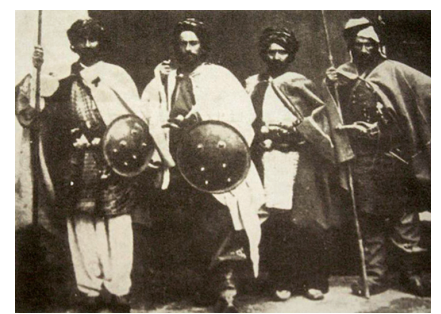

FIGURE 5

Taziyeh soldiers, from Nāṣer al-Dīn Šāh Qājār (r. 1848-1896) period

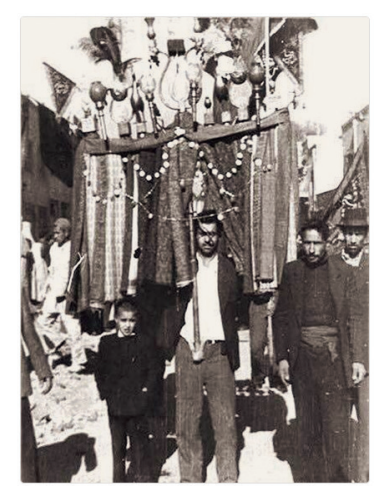

FIGURE 6

Picture of 'Ashurā procession in Tehran, 1909. On the 'alam a pair of peacocks and vases can be seen around the central banner. The objects and sculptures are fixed on the crossbar through a square base. 


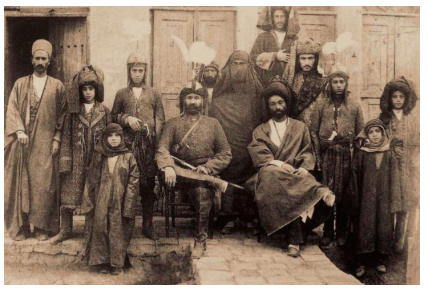

FIGURE 7

ta'ziyeh actors

FROM MĪRZĀ MEHDĪ HUĀN

ČEHREH-NĀMEH, 1910S

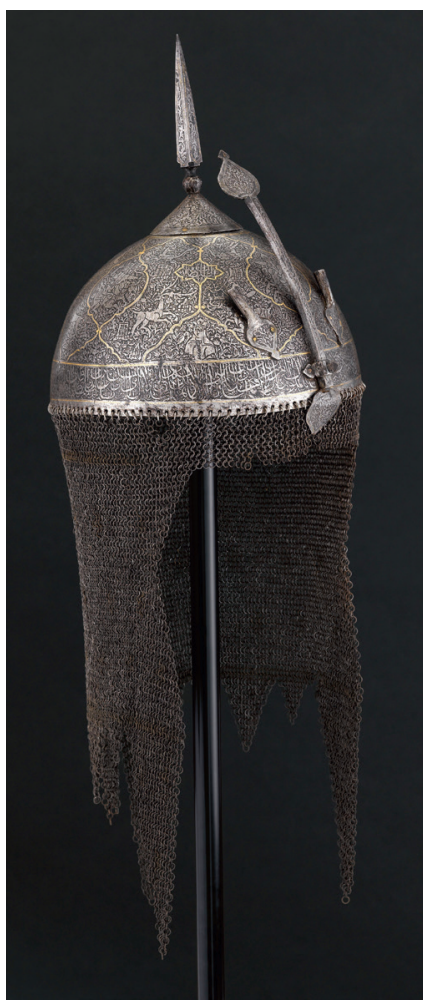

FIGURE 8

Helmet with hunting scenes, Iran, 19th century.Steel damascened with gold. H. $\max 61 \mathrm{~cm}$; D. $22 \mathrm{~cm}$; W. 1.469 kg. Paris, Musée des Arts Décoratifs (inv. AD 21627) (C) RMN - GRAND PALAIS (MUSÉE DU LOUVRE) / JEANGILLES BERIZZI
However, some of them, or more broadly some objects of the same types, were produced to be used for these devotional purposes. Although it cannot be systematic, their interpretation in this context remains to be discussed.

In contemporary processions and ritual theatre, one of the main types of objects displayed and worn are helmets. They have a round shape under a pointed top, a feather holder, and usually also a nose, and chain-mail neck protector. Helmets of this shape are represented in Qajar-period paintings of the Karbala events, like for example on a large tile panel from Shiraz. ${ }^{27}$ These helmet types are one of the most common objects preserved in European collections, along with shields and swords. The same type of helmet is recognizable on Qajar-period photographs of taziyeh actors (fig. 7-8). This model follows the Safavid type (fig. 3), well documented by dated and inscribed items. Heavier than the nineteenth and twentieth centuries costume-helmets (around $2 \mathrm{~kg}$ ), they were made of steel damascened with gold, and often inscribed with invocations and Quranic verses. $^{28}$ One of the most famous Safavid helmets of this type is inscribed with the name of Šāh 'Abbās (London, British Museum, inv. 1878,1230.772).The inscriptions say that the golden helmet was finished in $1035 / 1625^{-6}$, under the reign of the Shah, who protects the one who wears it. Another dated helmet (1088/1677) of this Safavid type is inscribed with the names of the Twelver Shi'ism Imams and holy figures. ${ }^{29}$

The round shields, which along with the helmets constitute the visual identity of the soldiers/martyrs' equipment, always appear in taziyeh, as can be seen in Qajar-period images (fig. 5). Some are also depicted in paintings of Karbala events, along with the curved sword ( ̌̌amšrir) that was typical of nineteenth-century costumes (fig. 10-11). ${ }^{30}$ Shields are still found on contemporary horizontal standards in processions. As attested by dated examples, the circular shield with bosses (covering the handle ring attachments fixed on the inside) is the only type used in Iran from the late Safavid until the Qajar period (eighteenth-nineteenth centuries). These are made from damascened steel and the interior is generally covered with velvet. The shields measure around $40 \mathrm{~cm}$ in diameter, and the border is usually inscribed. Often, poetic verses compare the object to a planet/star (Elgood, 1979, p. 16-18). This analogy (especially with the sun and the moon. See fig. 4) can be linked to the divine guidance exercized by the Imam (the solar and lunar poles). According to the same analogy, on one shield preserved in Paris - with six bosses, as often seen in nineteenth-century examples - the center of the circle is occupied by the sun and its sign, the lion, which is also a reference to Imam 'Alī, who is Assadullāh, or God's lion (fig. 9).

On 'Ashurā, the šamširzan or qamarzan participants in dasteh, wearing white shrouds, strike their heads with a sword (šamšı̈r) or a large dagger (qamar). Swords are also visible on 'alams, where they represent the martyr's arms and are used in the taziyeh by both Husayn's troops and those of his enemies. The most famous curved swords of Iran, made of damascened steel, were produced in Isfahan from the seventeenth to the early twentieth centuries. By 1920, only two swordsmiths were still active in the city (Kovács, 2010, p. 75). The sword types of the eighteenth-nineteenth centuries typically have steel or ivory (or bone) hilts and go with modest quality scabbards, covered in leather. The arms often carry Shici invocations on the blade. Plenty of them were bought by European collectors in the late nineteenth/early twentieth centuries, like two swords in the Musée des Arts Décoratifs, which the museum acquired in 1885 and 1908 (figs. 10-11).

Other costume elements made for devotional theatre were not inspired by military historical equipment, but may find their origins in the very rich visual past of epic literature (fig. 12-13), as they recall the attributes of some of the great kings and heroes of the Šăhnāmeh (Book of Kings), the greatest national epic written by the poet Firdawsi in the early eleventh century AD. Some demon helmets and maces are also depicted 

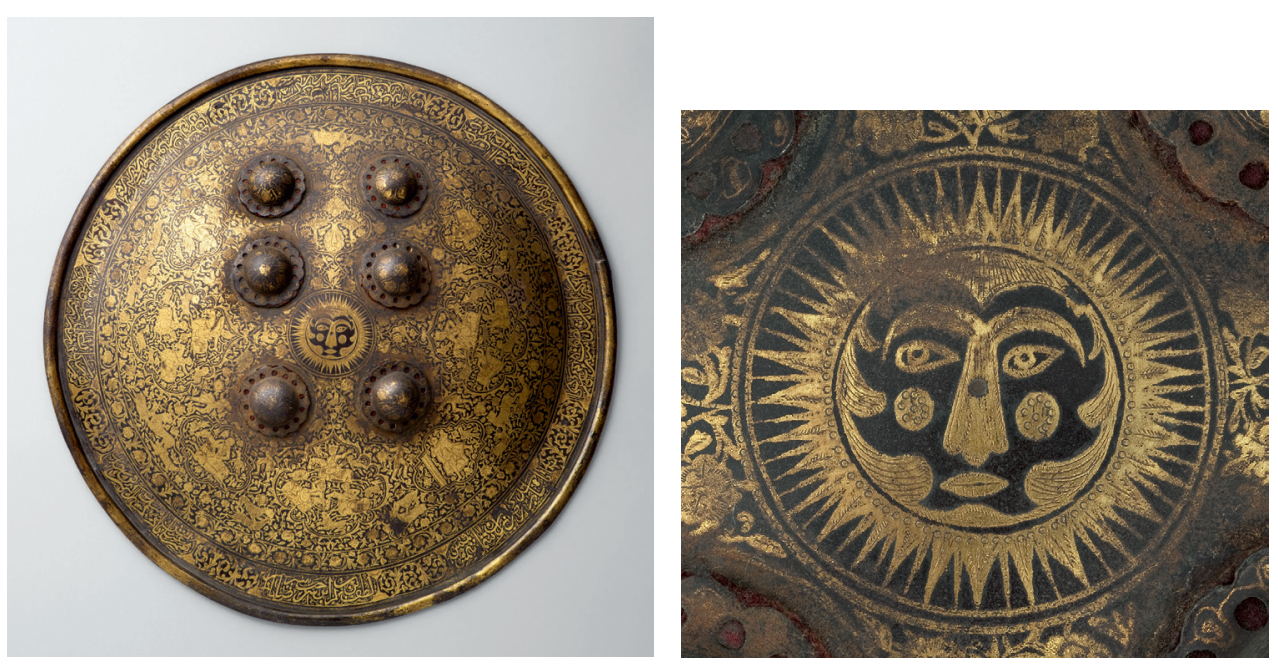

FIGURE 9

Shield with mask and hunting scenes. Iran, Steel damascened with gold. D. $40 \mathrm{~cm}$; W. $2.2 \mathrm{~kg}$. Paris, Musée du Louvre, R 869 (C) RMN - GRAND PALAIS (MUSÉE DU LOUVRE) / THIERRY Ollivier (LEFT); (C) MUSÉE DU LOUVRE, DIST. RMN - GRAND PALAIS / CLAIRE TABBAGH / COLLECTIONS NUMÉRIQUES (RIGHT).

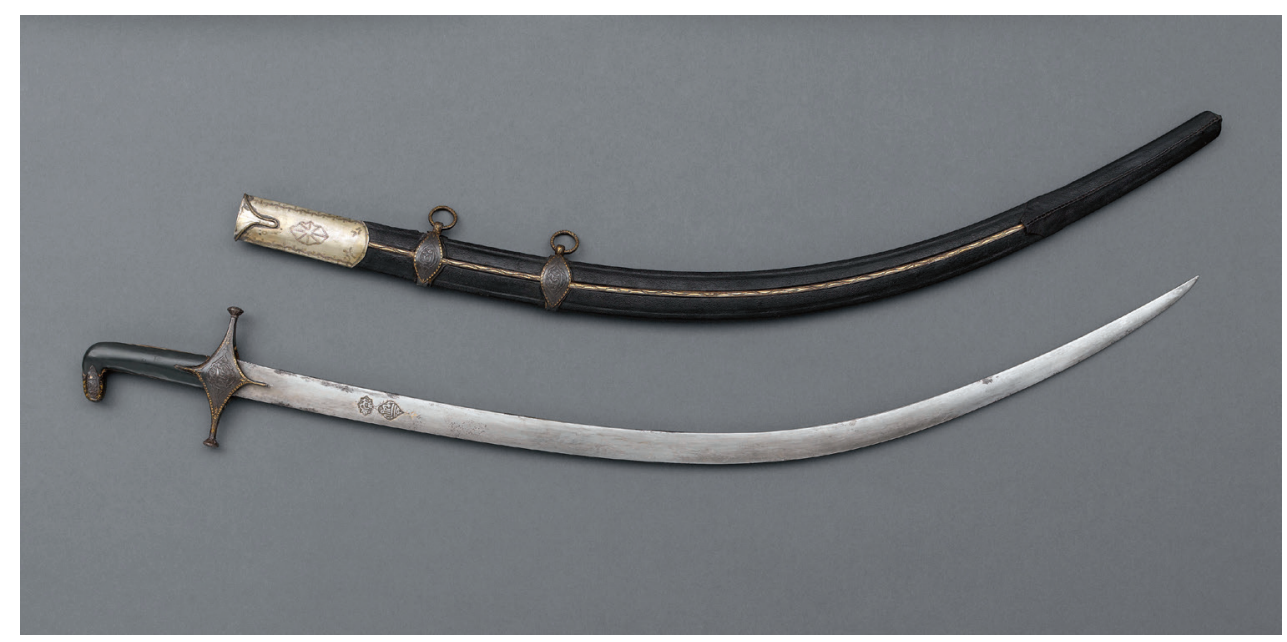

FIGURE 10

Sword and scabbard, Iran, 19th century. L. $96 \mathrm{~cm}$; Weight $1.11 \mathrm{~kg}$. Gift, Jules Maurice Audéoud, 1885. Maris, MAD, inv. AD 2583 (C) RMN - GRAND PALAIS (MUSÉE DU LOUVRE) / JEANGILLES BERIZZI

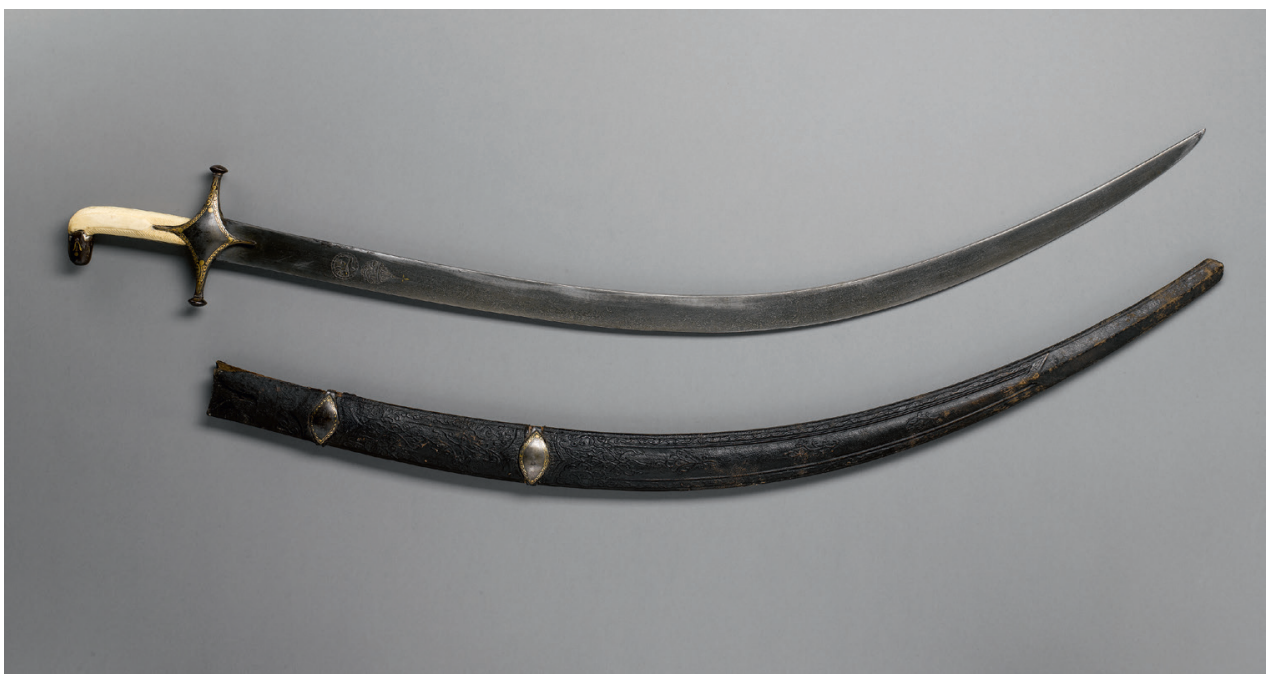

FIGURE 11

Sword and scabbard, Iran, 19th century. L. 95 cm; Steel. Gift, Belly, 1908. Jules Maurice Audéoud, 1885. Paris, MAD, inv. AD 14944 (C) MUSÉE DU LOUVRE, DIST. RMN - GRAND PALAIS / RAPHAËL CHIPAULT 
FIGURE 12

Complete demon helmet. AD 12584. D. $22 \mathrm{~cm} \mathrm{H.} \max 43 \mathrm{~cm}$. W. $1 \mathrm{~kg}$. Steel, damascened with silver and gold. Donated in 1906, Miss Tarn

(C) MUSÉE DU LOUVRE, DIST. RMN - GRAND PALAIS / CLAIRE TABBAGH / COLLECTIONS NUMÉRIQUES

FIGURE 13

Mace with a demon head.

AD 12583. Donated in 1906, Miss Tarn. H. 74.5 cm; D. $\max 11.5 \mathrm{~cm}$; Weight $0.336 \mathrm{~kg}$. Steel, traces of silver damascene

(C) MUSÉE DU LOUVRE, DIST. RMN - GRAND PALAIS / HERVÉ LEWANDOWSKI
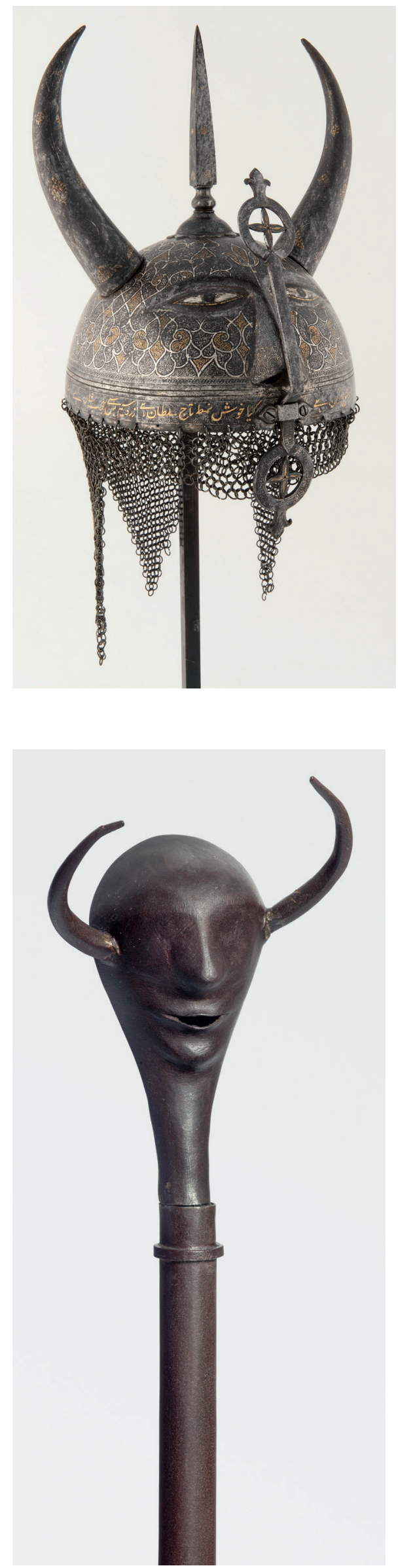
in representations of the Muharram martyrdom and its commemoration. They are more obviously identifiable as costumes because of their lighter weight and nonfunctional designs. Demon shaped maces were used for scenes (majles) in which the king of demons (jinns) appears with his army. There were also demon masks used for taziyeh, as evidenced by preserved objects and Qajar-period pictures. ${ }^{31}$ The animal-head maces produced in the second half of the nineteenth century, ${ }^{32}$ especially in Isfahan, were also made for the European market. The one preserved in Paris, MAD and illustrated here, comes from the same French collection as the demon helmet damascened with gold and silver. Both objects were brought back from Iran before 1906 (fig. 12-13). Traces of silver damascene are visible on the head of the demon, which is adorned with floral designs. He has an open mouth and seems to be smiling. The steel mass is made of several forged parts - the stick, the head and two horns - soldered together. The production and assemblage technics of this theatre weapon are identical to the ones observed on the animal sculptures produced for the horizontal standards (fig. 14-15), suggesting that both taziyeh and dasteh performance objects and signs have been made by the same artisans.

The sculptures (zoomorphic, fruit-shaped) and vessels (vases) that are still displayed on some of the monumental standards of Iran, are very close to the sculptures of the late Qajar period, and even to contemporary reproductions. The animal-shaped sculptures of the Qajar period sometimes appear as decorative objects, but mainly feature as elements on battle standards linked to Muharram and 'Ashurā, and therefore primarily serve a religious purpose. Associated with the religious ceremonies that developed during the Qajar period, these sculptures are not sacred objects per se, but participate, especially on 'Ashurā, in major devotional representations in modern and contemporary Iran.

Contemporary sculptures are similar to the ones from the Qajar period, and the descendants of nineteenth-century craftsmen who work in contemporary workshops and continue to supply the elements and sculptures for the 'alams. Although the production of metalworking related to devotional practices has declined a lot since the late Qajar period, sculptures of the same type were still produced at the end of the twentieth century, and still are today, especially in Isfahan. On these 'alams, the signs work as an intercession to the spiritual. They are the catalysts of a vision, a visualization process through which the objects shape a symbolic and intermediary world, as discussed by Christiane Gruber (2016). The sculptures, sometimes quite small, were and are parts of larger, much more important assemblages. They possess the symbolic function of representing Husayn and his martyrdom, the Karbala martyrs, and holy figures such as 'Alī and the Shici Imams. The sculptures and objects are the visual images of the passion of Imam Husayn in Karbala, and the symbolic representations of Imams, or linked to the Imams. The most frequently appearing "figures" are the deer, which refers to Imam Reza, the peacock (fig. 14), which refers to the Mahdi, and 'Ali the lion of God. The rooster announces Judgment Day through its prayers in the Shi'i cosmology. ${ }^{33}$ These allegorical creatures are evocations of the names and moral qualities of the Twelve Imams. Other steel objects, such as models of mosques and small bells, are seen on 'alams from the late Qajar period. Other animals, such as as lambs, sacrificed during the commemorations, could have been part of the 'alam assemblages if we take into account some isolated sculptures that have been preserved. ${ }^{34}$ This seems probable, because some offerings of food and drink are made to the Karbala martyrs during Muharram, and these votive offerings ( $\mathrm{nazr}$ ) are also represented by their steel presence on the 'alams (fig. 15-16). They are also ex voto supports: mirrors, feathers, textiles, and ribbons are put on or tied to the standards. ${ }^{35}$

Some of the zoomorphic sculptures preserved in the Louvre ${ }^{36}$ bear traces of soldering under their legs, showing that they were fixed on supports. Such supports of square 
FIGURE 14

Peacock, steel damascened with silver and gold; Iran, second half of the 19th century. Rennes, Musée des Beaux Arts

(C) GRAND PATRIMOINE DE LOIRE ATLANTIQUE, LABORATOIRE ARC'ANTIQUE

FIGURE 15

Pear with three leaves. Steel, damascened with gold. H. $12.5 \mathrm{~cm}$; D. $\max 10 \mathrm{~cm}$; Weight $0.424 \mathrm{~kg}$. MAD, inv. AD 41924 (C) RMN - GRAND PALAIS (MUSÉE DU LOUVRE) / MATHIEU RABEAU
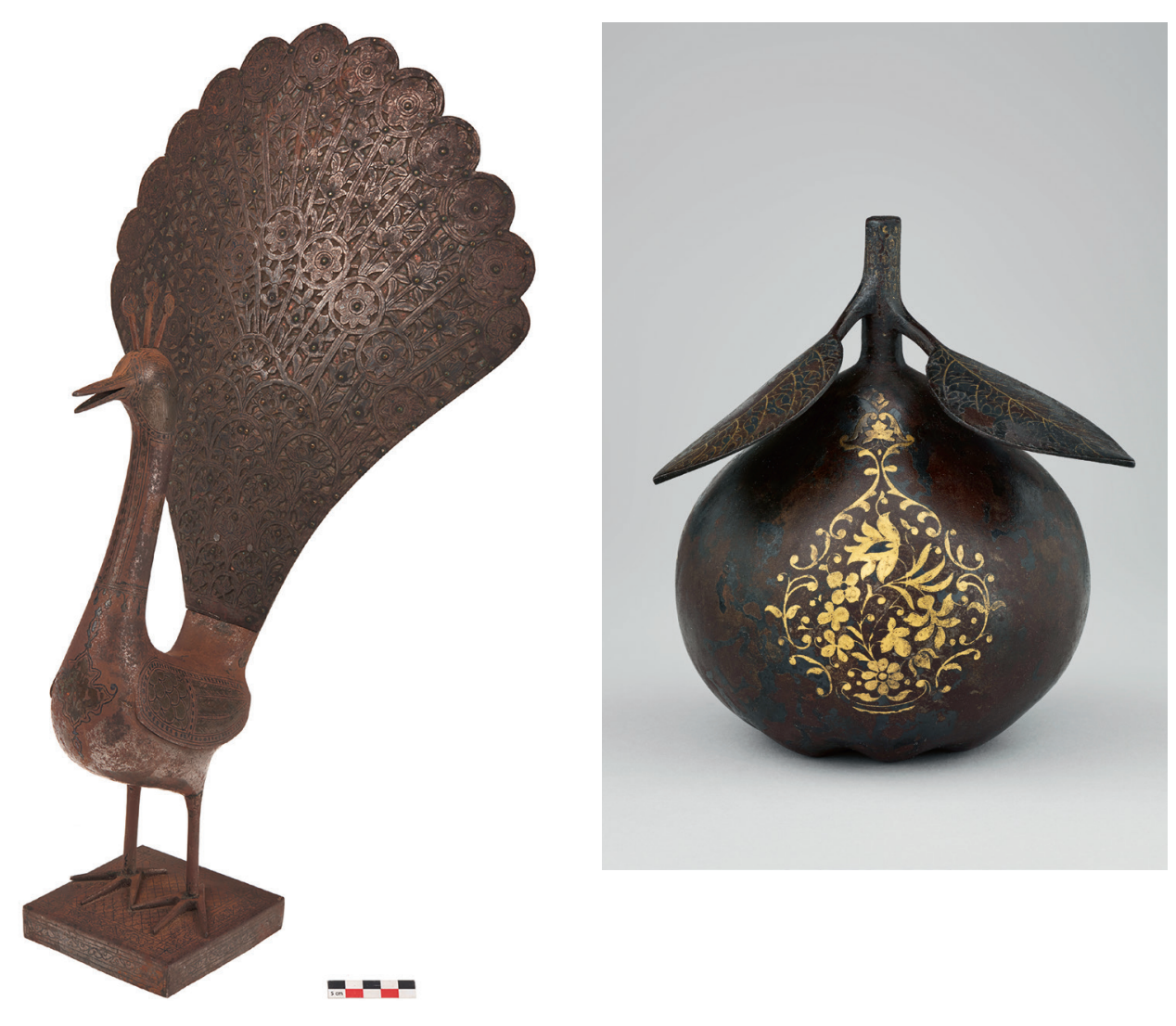

or rectangular shape are clearly visible on late Qajar crossbar 'alams (fig. 6). ${ }^{37}$ Others, like lambs and fruits (fig. 15), are made with a hole in the base, which allowed them to be placed on a vertical stick: a well-documented system that is also used to fix items on the square bases or the cross bar (fig. 1-2). These peculiarities of the isolated objects scattered throughout various collections suggests that their original purpose - or types of production - was mainly to be part of horizontal 'alam assemblages. This is also the case for two steel vases with floral designs, one slightly taller and heavier than the other, but which must have been made as a mirroring pair to be placed on a standard (fig. 16). Under the square base of the vase, a round cavity was probably created to attach the objects on the 'alam crossbar.

Steel, the Material of Shici Devotional Objects

Steel ( füläd), as first noted by James Allan, seems to be particularly linked to Shicism and Shici material culture. This metal seems to be the predominant material of the object-signs of martyrdom, and of devotional supports in Iran. Steel is worked by the blacksmith ( fülädgar, ahangar) and is generally inlaid (or, more properly, damascened, and thus called füläd-e jawhardār) with gold and silver. In this context, the material of the objects seems to be a timeless sign of the story of martyrdom, of the movement that engages bodies in devotion and representation, in the act of (re)living and (re)playing the martyrdom of Karbala.

The steel itself may also signify an epic dimension. Kaveh Ahangar (the blacksmith) is a hero of the $\check{S} \bar{a} h n \bar{a} m e h$. He revolts against Żaḥhāk and makes a banner with a leather apron, which evokes the story of 'Abbās, the 'alam-bearer of the Imam, who, at Karbala, died in an attempt to reach the river with his leather flask as a banner. Steel may also 
refer to the wrestlers, athletes who play a role in the rituals (in the processions and some parts of the taziyeh), and in the keeping of signs in gymnasiums or zurhaneh. It might not be coincidental that physical training of taziyeh actors - who might be members of a zurhaneh - is based on military techniques and derived from what is practiced in wrestling houses.

As mentioned earlier in this article, the novelist James Morier, who was in Tehran in the early nineteenth century, saw standards during a procession that took place before the beginning of a taziyeh. He describes a strong man carrying a banner made of what he calls tin, with Quranic inscriptions, about thirty feet in height with a crossbar. Morier was very impressed by the weight of the signs, carried by half-naked men (like wrestlers). The vertical 'alam that he saw was more likely made of steel, which, like tin, also has a grayish-white color when polished, as illustrated here by a fragment of an 'alam or door plaque (fig. 17).

From examples of Qajar-period and contemporary objects, and those on pictures, it is clear that votive gifts and sculptures do nevertheless often not have a gray-steel color, but a dark patina. This patina can be structural, a result of the heating of the material during production, but some of the Qajar-period objects preserved in the Louvre and restored between 2010 and 2018 were partly covered by a black compound made of paint or laquer. This overlay was found for instance on one piece of fruit (fig. 15), and it even covered the gold damascened compositions. Several animal sculptures that were examined also appeared to have an artificial black patina. This was the case for a pair of deer sculptures from Rennes, in the Musée des Beaux-Arts. ${ }^{38}$ The analysis of some samples of black color covering parts of the (very red and corroded) surfaces made clear that it was an overlay of organic nature, of arabic gum or some sort of lacquer. ${ }^{39}$ The practice of overlaying the objects with patina does not seem to be documented but this
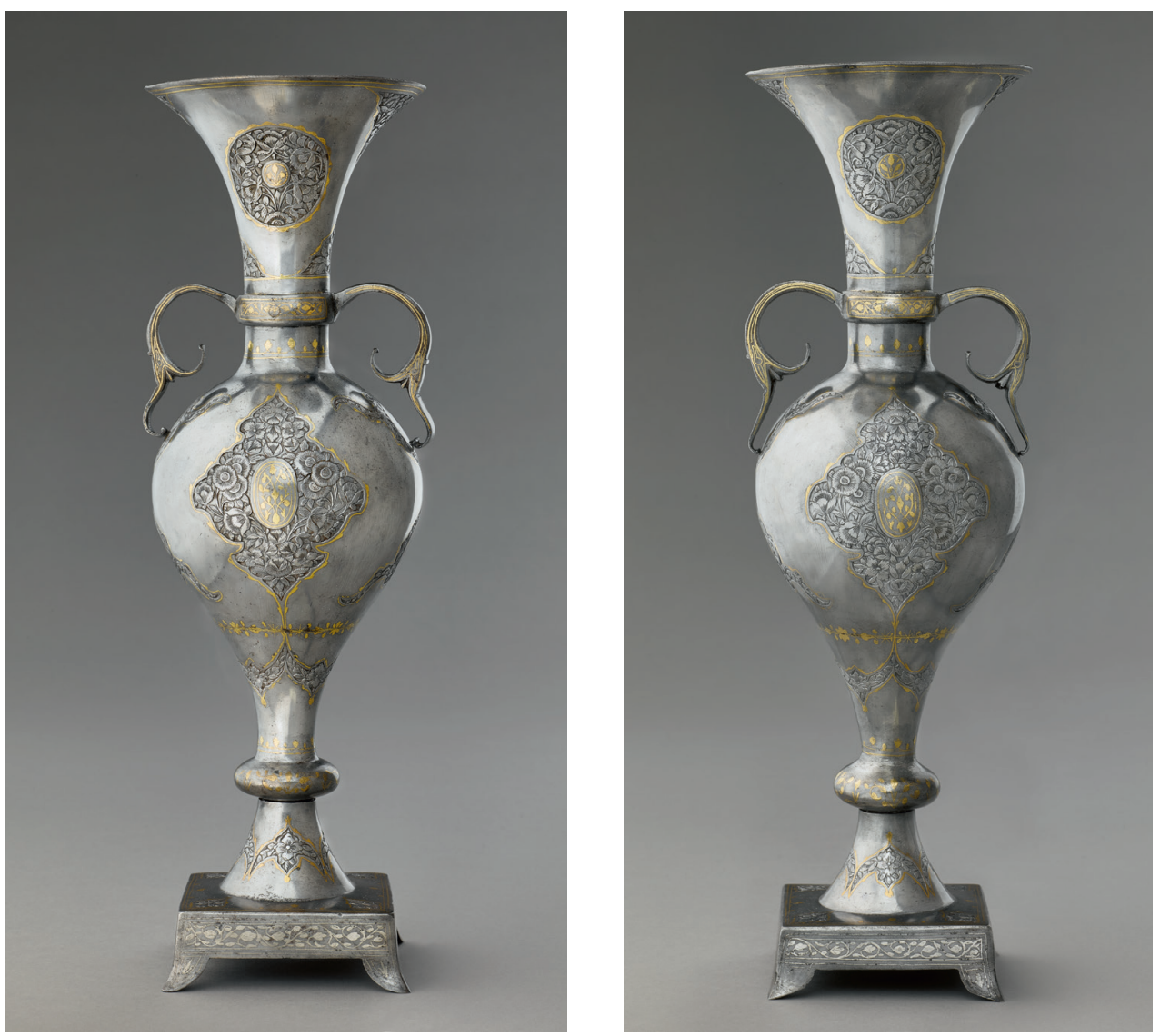

\section{FIGURE 16}

Pair of vases, Iran, c. 1850-19oo. Steel, damascened with gold. (H. 39-40 cm; D. max $12.7 \mathrm{~cm}$; Weight 1.328/1.355 kg). Paris, Musée des Arts Décoratifs, Gift, Goux, 1974, inv. AD 44628 and AD 44629

(C) MUSÉE DU LOUVRE, DIST. RMN - GRAND PALAIS / RAPHAËL CHIPAULT, BENJAMIN SOLIGNY 


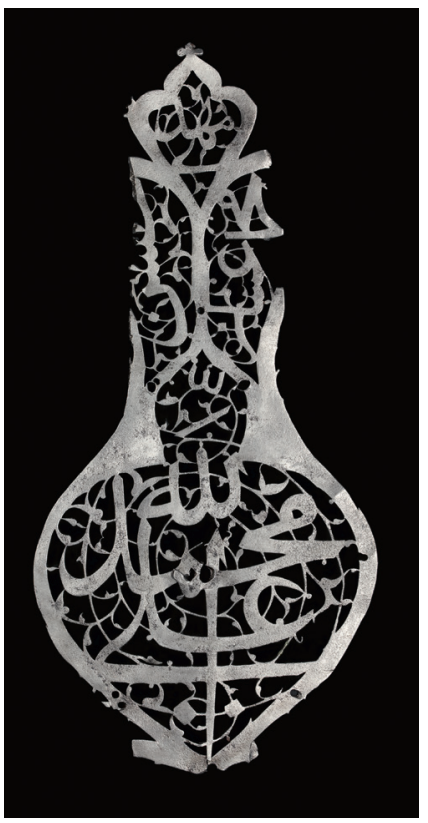

FIGURE 17

Fragment of 'alam or door plaque? Cut steel, inscribed in thuluth script on the top with the 12th and 11th Imams (Mahdi Muhammad and 'Askari Hasan) and in the round part with Allah, Muhammad, 'Alī. Iran, 19th century (?). H. $31 \mathrm{~cm}$; l. 14,6 cm; w. 0.7-1.2 mm; Weight $0.142 \mathrm{~kg}$. Bought in Paris? from Sivadjian, 1899. Musée du Louvre, DAI, OA 4097/2 (C) MUSÉE DU LOUVRE, DIST. RMN - GRAND PALAIS / HERVÉ LEWANDOWSKI issue of the black color - which is the color of Muharram - sometimes covering and hiding underlying materials which are steel, but also symbolic metals like gold (linked to the sun) and silver (linked to the moon), may hold a symbolic significance.

The steel productions developed during the nineteenth century were among the most innovative examples of metalwork in Iran at that time. The other, copper-alloy productions of metalworkers more or less exclusively relied on Safavid models. From European accounts, it is known that Qajar-period productions of weapons and armor were highly praised, as were the skills of Iranian smiths in forging steel. ${ }^{40}$ Steel production revolved around two major centers that are still the most important for the production of steel artifacts in Iran today: Isfahan (the Safavid capital from 1588 onward) and Tehran, which became the capital in 1796. Isfahan in the early seventeenth century was known for instance for the damascened sword maker Asadallāh of Isfahan. The city then became the major center for the production of armor and weapons (fig. 18). Under the Qajars, the reproduction of Safavid weaponry continued; a four-mirror armor type, čahār-āyinna in the name of Fatḥ-'Alī Šāh Qājār is for instance dated 1224/18og (London, Wallace Collection).

During the Qajar period, iron was extracted and prepared in Iran, but iron and steel were mainly imported from Russia and India in the form of leaves, bars, and pig iron or obtained through scrap melting. Willem Floor studied the production of these objects through documents of Isfahan guilds from the year 1870 . The role played by the guilds, already mentioned, is central to the patronage of Muharram ceremonies, and to the patronage of 'alams and their making. According to Murdoch Smith (1876), the most important center of production of engraved steel was Isfahan (fig. 18). He also writes that two types of precious metal work techniques were used to decorate the steel: the overlay of wires on a rough surface (which corresponds to damasquinure in French terminology and to damascened steel in English) and gold leaf gilding. He writes that inlay, that is to say the hammering of precious metals into a chiseled surface, had disappeared. Following the observations made by Wulff before 1941, the main examples of steel inlaid with gold were animal sculptures of religious signification, which were brought out for Muharram days. Wullf (1966) published pictures of the overlaying of a deer sculpture to illustrate the art of inlays observed during his field study of Iranian crafts.

As for the standards and sculptural elements that were developed during the second half of the nineteenth century, they were and still are made in wrought and overlaid steel. Whatever their purpose, whether purchased, produced as ornamental sculptures or related to Shici devotion, all the sculptures seem to have been created in workshops, which mainly supplied the 'alams. As discussed elsewhere, ${ }^{41}$ two sculptures preserved in the British Museum signed Hājjī 'Abbās (v. 1865-196o), and inlaid with ruby and turquoises, are suggestive of an object that can be used for ornamental purpose, but which appears to be mainly linked to the production of devotional performance objects. As James Allan discovered during an interview with his grandson in the early 199o's, Hājjī 'Abbās worked in Isfahan as an 'alam maker or 'alämat-saz in the family workshop for standards during the late nineteenth century. He produced animal-shaped sculptures for which he was famous: a peacock signed Haajjī 'Abbās is in the Iran-e Bastan Museum in Tehran. The inlaid and overlaid decorations were not made by him, but by specialized craftsmen. This division of work with respect to form and decoration was common for the makers of these sculptures and for the art of metalworking in general. The sculptures by Hājjī 'Abbās were made for the Muharram processions and some of them, like the deer, were, as recent as twenty-five years ago, still kept in a tea house in his neighborhood in Isfahan. As discussed by Szanto (2010), the workshop of the Bahman brothers in Isfahan also produced the same objects types in the 199os; 'alams, birds, animal sculptures, and vases. The shapes were wrought from big steel tubes. In Tehran, the art 
of metalworking continues until this day, but many of the older craftsmen consider it a disappearing art form. ${ }^{42}$

Steel and damascened steel are often used for the production of objects linked to Shici devotional practices in the public space, in popular rituals, and also for architectural elements in Shi'i sanctuaries. Under Muhammad Šāh Qājār (r. 1834-48), the army changed its equipment and adopted European-style uniforms: the Safavid styles of shields, armor, and helmets were no longer in use, and the Qajar style equipment was only used as theater costumes. ${ }^{43}$ The legitimizing copy provided the continuity of Safavid models' weapons and armors, made and sold by sword smiths and blacksmiths for the rituals and for the art market during the Qajar period (fig. 18). They perpetuated the objects used during the founding period of the great public rituals that centered around Imam Husayn's martyrdom and the Karbala drama.

The attributes and signs of these rituals are timeless, since the drama itself is replayed outside of time. But the visual references from Iran's official Twelver Shi'ism's past are also very strong. The Safavid-era model for performance objects lasts to the present day; despite the fact that these objects are not in use anymore, because of changes in military arms, garments, and protective gear in the nineteenth century. The visual reference was preserved. The same types of forged and damascened steel equipment were still produced during the Qajar period, and transformed into ceremonial costume. Despite some changes in the rituals (especially pertaining the shift in static/ambulatory rituals in the late Qajar period), the costumes used visually to allude Safavid reference and identity; like so many works of Qajar art did. They evoke the unified Twelver Shi'i state, its power and legitimacy, and take part in the foundation/codification of rituals in the public sphere. With the rituals built for the public sphere under the Safavids, some standardized practices and objects seem to have been put in place, which in a broad sense continued throughout the Qajar era, and well into the contemporary period to a certain extent.

The cosmic struggle and foundational Shi'a myth are played out in the historical time of the Safavids through the props, then in the Qajar period through the continuity of these props, and with the appearance of new visual supports for the story of the Karbala drama and its attributes. The continuity of the Safavid tradition, and the political legitimization of the Qajar era, are part of Shi'i symbolism and visual culture. These two historical periods overlap and mingle today. This relation to time and history could be called "performing the past in the present," and the ten days of Muharram and the organized processions could have been (...) in "time correspondence" with the "real' events of Karbala," as described in European accounts since the seventeenth century, ${ }^{44}$
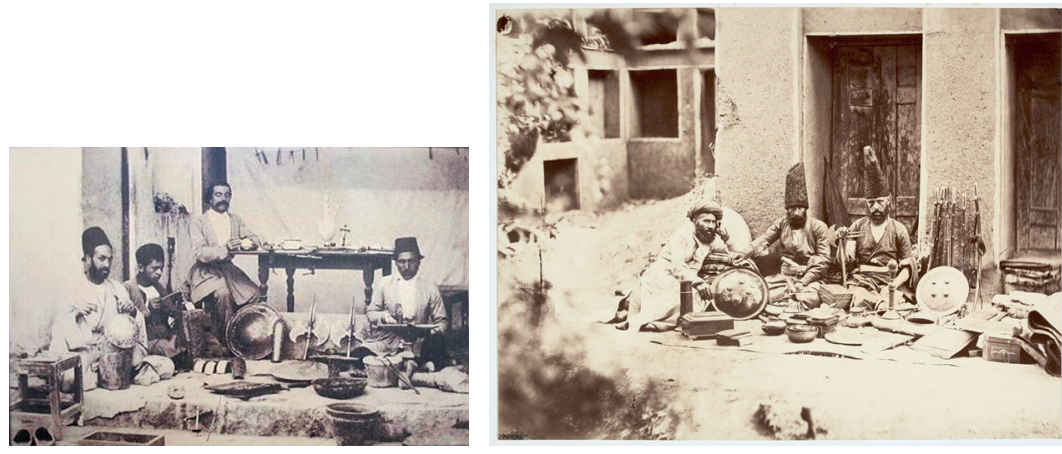

FIGURE 18

Makers and sellers of steel swords, axes and shields and objects in Isfahan and Tabriz, late Qajar period

(C) UNKNOWN (LEFT); LUIGI MONTABONE 1827 CA.-1877, TABRIZ, 1862. VENISE, BIBLIOTECA NAZIONALE MARCIANA (RIGHT) 
showing that what is documented from the Safavid period, enjoys continuity down to the present day. Historical time, as anchored in the founding event of Karbala martyrdom, and interior time, which has no historical, but only a spiritual dimension, evokes the eternal presence of the Imam and his martyrdom. This synchronism is experienced during the re-enactment of the events of Muharram.

\section{About the Author}

Annabelle Collinet is also an associate member of the CéSor UMR 8216 (EHESS/CNRS). Her work focuses in particular on the material culture of the Iranian and Indian worlds.

\section{Bibliography}

Aghaie K.S., (2004). The Martyrs Of Karbala: Shii Symbols and Rituals in Modern Iran, University of Washington Press.

Algar, H. (1991). Religious Forces in eighteenth and nineteenth century Iran. In: The Cambridge History of Iran, vol. 7, From Nadir Shah to the Islamic Republic. Cambridge University Press, pp. $705^{-31 .}$

Allan, J.W. (2012). The Art and Architecture of Twelver Shiism: Iraq, Iran and the Indian SubContinent. London, Azimuth Editions, 2012.

Allan, J.W. and Gilmour, B. (200o). Persian steel. The Tanavoli Collection. Oxford: Oxford University Press, 2000.

Avery, P. (1991). Nādir Shāh and the Afsharid legacy. In: The Cambridge History of Iran, vol. 7, From Nadir Shah to the Islamic Republic. Cambridge University Press, pp. 3-62.

Beeman, W.O, Ghaffari, M.B. (2005). Acting Styles and Actor Training in Ta'ziyeh. The Drama Review 49, Special Issue on Ta'ziyeh, pp. 48-6o.

Calmard, J. (1974). Le mécénat des representations de ta’zie. Le monde iranien et l'Islam, Volume 2, Paris: Editions de Boccard, pp. 73-126.

Caron, N. (1975). Le Ta'zieh, théâtre religieux iranien. The World of Music 17 (4), pp. 34-7.

Chelkowski, P.J. (1985). Shia Muslim Processional Performances. The Drama Review 29 (3), pp. $18-30$.

Chelkowski, P.J. (1989). Narrative Painting and Painting Recitation in Qajar Iran. Muqarnas 6, pp. 98-111.

Chelkowski, P.J. (1991). Popular entertainment, media and social change in twentieth century Iran. In: The Cambridge History of Iran, vol. 7, From Nadir Shah to the Islamic Republic. Cambridge: University Press, Press, pp. 765-814.

Chelkowski, P.J. (1994). Dasta. Encyclopaedia Iranica. Volume 7 (fasc. 1), pp. 97-100.

Chelkowski, P.J. (2009). Ta`zia. Encyclopaedia Iranica. https://iranicaonline.org/articles/tazia.

Chelkowski, P.J. (2010). Time out of Memory: Ta'ziyeh, the total drama. In: P.J. Chelkowski, ed., Eternal Performance, Taziyeh and other Shiite rituals. Calcutta: Seagull Books, pp. 1-18.

Collinet, A. (2018). Rondes-bosses d'acier, les sculptures de 'alam. In: G. Fellinger and C. Guillaume, eds., L'Empire des roses: chefs-d'œuvre de l'art persan du XIX ${ }^{e}$ siècle. Musée du Louvre-Lens: Snoeck, pp. 92-7.

Corbin, H. (1971). En Islam iranien. Aspects spirituels et philosophiques. 1. Le shîisme duodécimain. Paris: Gallimard, reprint 2007.

D'Souza, D. (1998). In the Presence of the Martyrs: the 'Alam in Popular Shïi Piety. The Muslim World 88 (1), pp. 67-79.

Elgood, R. (1979). Islamic Arms and Armour. London: Scolar Press. 
Flaskerud, I. (2010). Visualizing belief and piety in Iranian Shiism. New York: Continuum Publishing Group.

Floor, W. (2003). Traditional Crafts in Qajar Iran (1800-1925). Costa Mesa, CA, Mazda.

Floor, W. (2005). The History of Theater in Iran. Washington D.C.: Mage Publishers.

Ghaffary, F. (1984). Evolution of Rituals and Theatre in Iran. Iranian Studies 17 (4), pp. 361-89.

Gleave, R., ed. (2004). Religion and Society in Qajar Iran. London and New York: Routledge.

Gruber, C. (2016). Nazr Necessities: Votive Practices and Objects in Iranian Muharram Ceremonies. In: I. Weinryb, ed., Ex Voto: Votive Giving Across Cultures. New York: Bard Graduate Center, pp. 246-75.

Hambly, G.R.G. (1991). Āghā Muḥammad Khān and the establishment of the Qājār Dynasty. In: The Cambridge History of Iran, vol. 7, From Nadir Shah to the Islamic Republic. Cambridge: University Press, pp. 104-43.

Kelényi, B. and Svántó, I., eds. (2010). Artisans at the Crossroads, Perisan Arts of the Qajar Period (1796-1925). Budapest: Ferenc Hopp Museum of Eastern Asiatic Arts.

Khosronejad, P., ed. (2012). The Art and Material Culture of Iranian Shi'ism. Iconography and Religious Devotion in Sh'i Islam. London, New York: I.B.Tauris.

Koczor, M. (2016). La couleur d'origine. Les objets et armes d'art islamique en base fer et décors incrustés. Master 2, Histoire de l'art et du patrimoine, Matériaux du patrimoine culturel et archéométrie. Université Bordeaux Montaigne.

Marzolph, U. (2019). The Visual Culture of Iranian Twelver Shi'ism in the Qajar Period. Shii Studies Review 3 (1-2), pp. 133-86.

Melikian-Chirvani, A.S (1992). Qajar metalwork: a study in cultural trends. In: C.E. Bosworth, and C. Hillenbrand, eds., Qajar Iran: Political, Social and Cultural Change, 1800-1925. Mazda Publishers, pp. 311-28.

Mervin S., and Parsapajouh, S., eds., (2020). Religions en Iran, Archives de Sciences Sociales des Religions 189, Paris: éditions EHESS.

Mleziva, J. (2013). A variety of decorative steel objects in the Islamic art collection of the Náprstek Museum. Annals of the Náprstek Museum 34 (1), pp. 15-42.

Moshtagh Khorasani, M. (2006). Arms and Armor from Iran, The Bronze Age to the End of the Qajar Period. Tübingen: Legat.

Murdoch Smith, R. (1876). Persian Art. London: Chapman and Hall.

Najand, S., and Khajehi, Y. (2015). Le ta'zieh: A la croisée de l'histoire, de la religion et du théâtre. Paris: L'Harmattan.

Nematollahi Mahani, M.A. (2013). The Holy Drama. Persian Passion Play in Modern Iran. Leiden Univeristy Press.

Parsapajouh, S. (2016). Le mois de Moharram: pratiques rituelles et construction identitaire. In: Au cœur d'un bidonville iranien. De Zurâbâd à Islamâbâd, Paris, Karthala; Téhéran, Ifri, pp. 267-310.

Parsapajouh, S. (2019). Religiosités entre étatisation et réappropriation populaire. Les cérémonies de Ashura en Iran. In: S. Tersigni, C. Vincent-Mory, and M.C. Willems, eds., Appartenances in-désirables. Le religieux au prisme de l'ethnicisation et de la racisation. Paris: Editions Pétra, pp. 169-89.

Perry, J. (1991). The Zand Dynasty. In: The Cambridge History of Iran, vol. 7, From Nadir Shah to the Islamic Republic. Cambridge: University Press, Press, pp. 63-103.

Pigott, V.C. (1984). Āhan. Encyclopcedia Iranica. I/6, pp. 624-33; updated version (2011) at http:// www.iranicaonline.org/articles/ahan-iron.

Rahimi, B. (2012). Theater State and the Formation of Early Modern Public Sphere in Iran. Studies on Safavid Muharram Rituals, 1590-1640 CE. Leiden, London: Brill.

Rauh, E.L. (2013). Thirty Years Later: Iranian Visual Culture from the 1979 Revolution to the 2009 Presidential Protests. International Journal of Communication 7, pp. 1316-43. 
Rizvi, K. (2003). Religious Icon and National Symbol: The Tomb of Ayatollah Khomeini in Iran. Muqarnas 20, pp. 209-24.

Rizvi, K. (2015). The Incarnate Shrine. Shi'ism and the Cult of Kingship in Early Safavid Iran. In: C. Hahn and H. Klein, eds., The Cult of Relics in Byzantium and Beyond. Dumbarton Oaks Research and Collection, pp. 289-307.

Scarce, J. (1991). The arts of the eighteenth to twentieth centuries: Metalwork. In: The Cambridge History of Iran, vol. 7, From Nadir Shah to the Islamic Republic. Cambridge: University Press, Press, pp. 939-44.

Shahriari, K. (2006). Breaking Down Borders and Bridging Barriers: Iranian Taziyeh Theatre, thesis submitted for the Degree of Doctor of Philosophy, School of Media, Film and Theatre University of New South Wales.

Szanto I. (2010). The Repository of Shi'ite Religious Accessories. In: B. Kelényi and I. Szanto, eds., Artisans at the Crossroads, Persian Arts of the Qajar Period (1796-1925). Budapest: Ferenc Hopp Museum of Eastern Asiatic Arts, pp. 130-39.

Vivier-Muresan, A-S. (2006). Les rites d'âshurâ dans un village de l'Iran contemporain: révélateur privilégié d'un monde rural en mutation. Anthropology in the Middle East 1 (1), pp. 63-79.

Vivier-Muresan, A-S. (2020). Rites d'Achoura et affirmations communautaires. In: S. Mervin and S. Parsapajouh, eds., Religions en Iran, Archives de Sciences Sociales des Religions 189, Paris: EHESS, pp. $55^{-72 .}$

Wulff, H. (1966). Traditional Crafts of Persia: Their Development, Technology, and Influence on Eastern and Western Civilization. Cambridge MA and London: Miт Press.

\section{Notes}

$1 \quad$ Khosronejad (ed.) 2012, Marzolph 2019. Allan's founding publication (2012) nevertheless gave the largest overview of the portable arts linked to Shici devotion and culture; see also Gruber, 2016. For architecture of devotion and pilgrimage, especially from Iran during the Safavid period, see Rizvi, 2003 and 2015 .

2 The rituals documented in Tehran today, and that take place in large to medium cities with steel objects, are not uniformly performed throughout the whole country. For Muharram and the different rituals performed, their changes and social structures in urban and rural contexts, see especially the contributions of S. Parsapajouh, 2016; A-M. Vivier-Muresan in Mervin and Parsapajouh (ed.), 202O. Muharram ceremonies are often performed in cities and villages without the object types published here. For instance, the presence of an 'alam carried in front of the procession may be a recent development and imported from a large city model of Muharram processions (Vivier-Muresan, 20o6, especially pp. 74-6).

3 See in particular https://www.alamy.com/search.html?page $=3 \& p s=100 \& p n=1 \& c b s t o r e=0 \& q \mathrm{t}=\mathrm{mu}$ harram-rituals; http://www.payvand.com/news/12/nov/122o.html; https://www.shutterstock.com/ fr/search/ashura; http://www.iranreview.org/content/Documents/Muslims-Mark-Martyrdom-Anni versary-of-Imam-Hussein.html; Parsapajouh, 2016.

4 Especially Moshtagh Khorasani, Arms and Armor from Iran, The Bronze Age to the End of the Qajar Period, Legat, Tübingen, 2006. This book approaches the question of steel arms/accessories types involved in taziyeh during the Qajar Period.

$5 \quad$ Fellinger and Guillaume (dir.) L'Empire des roses: chefs-d'ouvre de l'art persan du XIX ${ }^{e}$ siècle, cat. de l'exposition, Musée du Louvre-Lens, Éditions Snoeck, 2018.

6 For this notion, and for the constant earthly/spiritual dimensions; the relation to historical/spiritual time notions (see below), as well as for the aspects of the doctrine of the Imamate in Twelver Shicism, see Corbin, 1971.

7 See this article: www.theguardian.com/world/iran-blog/2014/nov/o4/iran-alam-dying-art-shia-cere mony and Kelényi and Svántó (ed.), 2010.

8 These accounts were studied and used mainly by Chelkowski, Calmard, Floor, and Shahriari, whose works can be found in the bibliography.

9 See the images and movies taken by camera operators sent from France to Iran in the early twentieth century (Archives de la planète, musée Albert Kahn, Boulogne-Billancourt.).

$10 \quad$ See note 4 . 
11 The monumental signs or 'alamat are brought out on the eve of 'Ashurā. They are devotional objects linked to takiyeh or husayniyeh, where they are kept. In each neighborhood the members of bazar guilds or religious societies gather during Muharram and for funerary processions. The 'alamat are the orders and possessions of different social groups who own at least one, as a guild (șenf); a religious organization (hay'at-e madhabì) or a town or village district (mahalla). The names of these communities appear on the standards. Outside of Muharram, the huge standards are also kept in gymnasiums or westlers houses (zürhāneh), as these very heavy steel assemblages are often manipulated by westlers. For the description and use of the 'alams pictured during the rituals observed in 2007 and reproduced here (fig. 1-2), see Parsapajouh 2016.

Gruber 2016.

13 See, for instance, the description of the writer and novelist James Morier, describing a taziyeh scene in which after Husayn's death, a lion appears from the desert and covers the martyrs' bodies with earth (Shahriari 2006, p. 54).

14 A lion sculpture can be seen, for instance, in pictures on the back of the throne of Muẓaffar 'Alī Šāh Qājār (r. 1896-1907).

15 On the Safavid dynasty and the transferred charismatic authority to Šāh Isma īl who declared himself imam (guide), see Rizvi 2015 .

16 See Floor 2005 for accounts on Shi'i rituals described by European witnesses.

17 For the early sixteenth century devotional treasure of Ardabil, see Rizvi 2015, esp. pp. 298-299 et p. 307 .

18 See Calmard and Allan in Encyclopaedia Iranica, vol. I fasc. 8 pp. $785^{-91 .}$

19 For the craftsmen and guilds and their role in the rituals, see Babayan 2002, p. xli., pp. 162-5, p. 182, 225-9.

$20 \quad$ Rahimi 2012, p. 224-5. Isfahan became the Safavid sultans' Capital city in 1588.

21 Ibid. p. 225 and p. 23 o.

22 For the origins and establishment of the Qajar dynasty, see Algar,1991; Hambly, 1991.

23 For this period, see Perry, 1991 and Algar, 1991.

24 Avery 1991, p. 13.

25 Description in Shahriari 2006, p. 49-5o, for the engravings see fig. $3^{-4}$.

26 Kovacs 2010 chap. 17, p. 130-7, The Repository of Shi'ite Religious Accessories is, to my knowledge, the only article published on a museum collection about arms and sculptures in this context.

27 This very high-quality tile panel is situated in the Imāmzādeh Ibrāhìm, and studied and reproduced by Marzolph, 2019, p. 157-6o, see fig. 27 for the helmets mentioned here.

28 For instance, in the Military Museum, Tehran (inv. 3), see Moshtagh Khorasani, 20o6, p. 716.

29 Furusiyya Art Foundation, inv. R83o, Mohamed (dir.), 2007, n $3^{21}$ p. 334.

$3^{\circ}$ On the tile panel mentioned above, in a scene representing Abū l-Fazl 'Abbās companion (Marzolph 2019, fig. 28 p. 161).

31 Ghaffary, 1984, p. 369.

$32 \quad$ Kovács S. 2010 p. 78.

33 Amir-Moezzi, 1993, p. 318.

34 Lamb of forged and damascened steel (H. 19 cm; L. $20 \mathrm{~cm})$, Paris, MAD, inv. AD 45343.

35 Gruber, 2016.

$3^{6}$ Mainly from the Musée des Arts Décoratifs collection, on loan in the Department of The Arts of Islam (DAI) since 2006. Traces of tin soldering are, for instance, visible under the legs of one bird, made of forged and damascened steel (H. 13 cm), Paris, MAD, inv. AD 14377.

See also the 'alam exhibited in Louvre-Lens, 2018, collection of the Musée du Quai Branly-Jacques Chirac, inv. 70. 2013.4.1, with the same assemblage system of sculptures and banners on square bases, attached on the crossbar.

38 Fellinger and Guillaume (dir.) L'Empire des roses: chefs-d'oeuvre de l'art persan du XIX ${ }^{\mathrm{e}}$ siècle, cat. de l'exposition, Musée du Louvre-Lens, Editions Snoeck, 2018, n78 p. 93.

39 Koczor 2016, p. 22.

$40 \quad$ Scarce 1991, p. 944.

41 Collinet 2018.

42 "Meeting the last masters of alam, a dying art" The Guardian, Tuesday 4 November 2014.

43 Scarce 1991, p. 944.

44 Babayan 2002 p. 204, p. 221. 